\title{
Communication
}

[Comunicação]

\section{Use of F57 bags by the semi-automatic in vitro technique of gas production}

[Uso de sacos F57 pela técnica in vitro semi-automática de produção de gases]

\author{
A.P.S.F. Amaral ${ }^{1}$, S.G. Coelho ${ }^{1 *}$, T.R. Tomich ${ }^{2}$, R.M. Maurício ${ }^{3}$, L.C. Gonçalves ${ }^{1}$, \\ S. Rocha e Silveira ${ }^{3}$, O.S. Pires Neto ${ }^{1}$, J.A.S. Rodrigues ${ }^{4}$ \\ ${ }^{1}$ Escola de Veterinária - UFMG - Belo Horizonte, MG \\ ${ }^{2}$ Empresa Brasileira de Pesquisa Agropecuária - Embrapa Gado de Leite - Coronel Pacheco, MG \\ ${ }^{3}$ Universidade Federal de São João Del-Rei - DEPEB- São João Del-Rei, MG \\ ${ }^{4}$ Empresa Brasileira de Pesquisa Agropecuária - Embrapa Milho e Sorgo - Sete Lagoas, MG
}

In vitro techniques based on the production of gases during ruminal fermentation simulate the ruminal environment and ruminants digestive processes (Theodorou et al., 1994). These techniques allow the description of ruminal fermentation kinetics and also, indirectly, to estimate animal consumption (Blümmel, Ørskov, 1993). Therefore, these techniques have contributed for the studies of forages (Getachew et al., 1998).

The semi-automatic in vitro gas production technique (Maurício et al., 1999) enables the evaluation of a large number of substrate, presents high repeatability and offers the possibility to describe the rumen fermentation kinetic, estimating the rate and the extension of degradation for different foods and diets. Moreover, it is a low cost technique if compared to others in vivo techniques (Guimarães Júnior et al., 2008).

This technique was developed at the University of Reading (England). It is based on the measurement of the pressure of gases produced by the anaerobic degradation of substrate incubated in fermentation flasks containing ruminal liquid and a buffering culture medium. Afterwards, the pressure data were used to calculate the volume of gases by means of a regression equation $(\mathrm{P} \times \mathrm{V})$ specific for each laboratory where the technique was implemented. The relationship between $\mathrm{P}$ and $\mathrm{V}$ is dependent on the altitude and, therefore, varies according to the geographic position of each research center (Mauricio et al., 2003). Maurício et al. (1999) have modified the technique described by Theodorou et al. (1994) eliminating the need for manual measurements of gas volume and considering the use of the equation derived from the relation between $\mathrm{P}$ and $\mathrm{V}$. This way, the degradation kinetics, more specifically the initial period of lag phase fermentation, could be described with greater accuracy due to the larger number of measurements and therefore were able to contribute to studies linked to feed evaluation for ruminants.

The technique described by Maurício et al. (1999) uses glass crucibles with porosity 1 and borosilicate plaques for filtering the material from the in vitro fermentations. However, when the analyzed sample is a substrate with high starch concentration (ex. concentrated), this process becomes inefficient due the blockage of the pores by sample residues. Alternatively, the use of the F57 (Ankom ${ }^{\circledR}$ ) bag, in lieu of the filter crucibles, could avoid the filtering process since the previously weighed bag would be removed from the flask, dried and weighed for quantification of the sample without interference of the filtration. However, it is necessary to reduce the amount of sample incubated; since, according to recommendation from Ankom ${ }^{\circledR}$ (New York City, New York State, United States), wthese bags were designed

Recebido em 24 de junho de 2013

Aceito em 30 de julho de 2014

*Autor para correspondência (corresponding author)

E-mail: sandragesteiracoelho@gmail.com 
to store samples up to 0.8 gram. Due to the reduction of the amount of incubated sample, it also becomes necessary to reduce the volume of culture medium and inoculum, in order to preserve the original relationship described for Maurício et al. (1999).

Therefore, the objective of this study was to develop an equation that can be used to calculate the volume of gases produced using the pressure data obtained from the in vitro fermentation of substrate incubated in F57 bags $\left(\right.$ Ankom $^{\circledR}$ ). The Federal University of Minas Gerais (UFMG) ethical committee (CETEA n. 66/2011) approved all the procedures of this research. The experiment was carried out at the Laboratory of in vitro Gas Production, of Veterinary School at the Universidade Federal de Minas Gerais (UFMG), Brazil, located at an altitude of $836 \mathrm{~m}$. Sixty-four samples of sorghum (BRS 506) were used. The samples were pre-dried at $55^{\circ} \mathrm{C}$ and grounded $(1 \mathrm{~mm})$ including individual parts of the plant (stalk, leaf and panicle) as well as the entire plant. The values of dry matter, crude protein, neutral detergent fiber, acid detergent fiber and lignin fiber, following methods of AOAC (1990), are described in Table 1.

Table 1. Chemical composition of forage samples from the whole plant and plant fractions of the sweet sorghum variety

\begin{tabular}{|c|c|c|c|c|c|c|c|c|c|c|}
\hline \multirow{3}{*}{ Sample } & \multicolumn{10}{|c|}{ Chemical composition (\% DM) } \\
\hline & \multicolumn{2}{|c|}{ DM (\%) } & \multicolumn{2}{|c|}{$\mathrm{CP}$} & \multicolumn{2}{|c|}{ NDF } & \multicolumn{2}{|c|}{$\mathrm{ADF}$} & \multicolumn{2}{|c|}{ Lignin } \\
\hline & Mean & SEM & Mean & SEM & Mean & SEM & Mean & SEM & Mean & SEM \\
\hline $\begin{array}{l}\text { Entire } \\
\text { plant }\end{array}$ & 24,8 & 0,6 & 6,3 & 0,5 & 52,4 & 0,8 & 31,9 & 0,6 & 7,3 & 0,2 \\
\hline Stalk & 21,5 & 0,4 & 0,6 & 0,1 & 46,6 & 0,6 & 29,3 & 0,5 & 4,6 & 0,1 \\
\hline Leaves & 34,9 & 1,4 & 11,7 & 0,3 & 75,2 & 6,9 & 41,5 & 0,9 & 13,6 & 1,2 \\
\hline Panicle & 45,3 & 2,4 & 9,8 & 0,1 & 47,1 & 2,7 & 23,6 & 1,4 & 9,5 & 0,3 \\
\hline
\end{tabular}

The samples (0.5 gram) were placed in F57 $\left(\right.$ Ankom ${ }^{\circledR}$ ) bags, previously weighed, and hot sealed. The bags were incubated in glass flasks (160mL) previously gasified with $\mathrm{CO}_{2}$ aiming at maintaining anaerobiosis within the bags. Flasks containing only ruminal liquid, culture medium (blanks) and empty F57 (Ankom ${ }^{\circledR}$ ) bags were included as control. In each flask, $45 \mathrm{~mL}$ of culture medium were manually added (Theodorou et al., 1994) and later sealed with a silicone stopper and kept at $4^{\circ} \mathrm{C}$ during the night previous to the inoculation. Five hours before inoculation, the flasks were placed in an incubator for stabilization of the temperature in accordance with the ruminal environment $\left(39^{\circ} \mathrm{C}\right)$. The ruminal inoculum was removed from an adult bovine fistulated in the rumen which was kept in a plot of Paspalum notatum and fed two kilograms of a corn and soybean meal concentrate (220g kg/DM of protein) for eight days prior to the collection of the inoculum. The ruminal liquid was removed and stored in previously warmed thermal bottles. In the laboratory, the ruminal liquid was filtered in two layers of cotton gauze, subject to a continuous
$\mathrm{CO}_{2}$ injection and kept in a warm thermostatic bath at $39^{\circ} \mathrm{C}$. The inoculation was done by means of an injection of $5 \mathrm{~mL}$ of inoculum per flask, using a plastic syringe. A Luer Lock valve with three exits was connected to a $60 \mathrm{~mL}$ syringe and to a pressure transducer (T443A, Bailey \& Mackey, England). A needle (for perforation of the silicone cork) was used for measuring the volume (syringe) and pressure (transducer) of the gases produced in the interior of the fermentation flasks. After the insertion of the needle in the flask, through the stopper, internal pressure was recorded. Afterwards, while rotating the valve (Luer Lock), the accumulated gases pushed the syringe's piston up to the point when the pressure recorded by the transducer reached zero, which was the indication that all gases had been removed from the flask. This was the moment when the volume of gases produced was measured according to the reading in the graduated syringe (Fig. 1). Simultaneous $\mathrm{P}$ and V data were obtained, with measurements at $0,2,4$, $6,8,10,12,15,19,24,30,36,48,72$ and 96 hours after inoculation. 


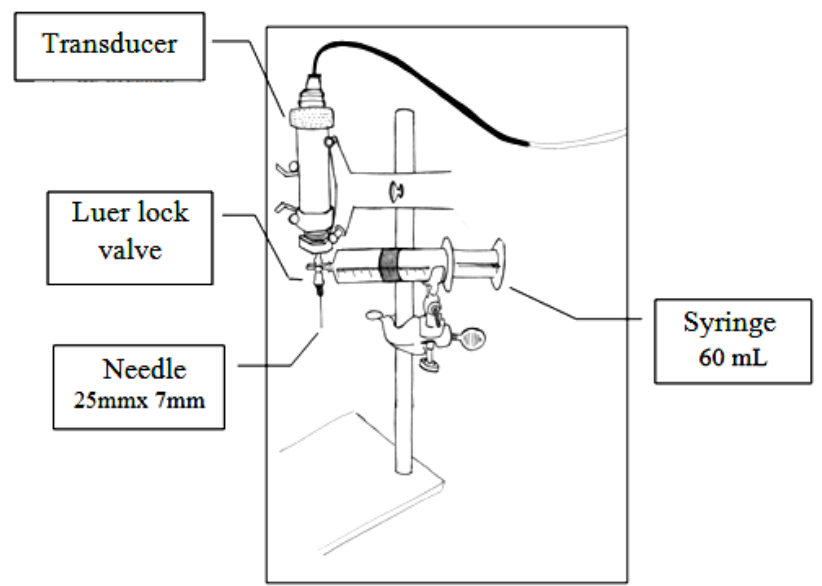

Figure 1. Schematical drawing of the equipment used for measuring pressure and volume of the gases during in vitro fermentation.

The polynomial regression procedure was applied for data analysis using SAEG (Statistical and Genetics Analyses System), according to Ribeiro Júnior (2001), in which the volume of gases was considered a dependent variable and pressure an independent variable.

Pressure ranged from 0 the 4.8 psi and volume from 0 to $36.7 \mathrm{~mL}$, considering data obtained from 474 observations (Figure 2). According to Theodorou et al. (2004), the maximum pressure recommended for the in vitro system of gas production is $7 \mathrm{psi}$, since for values above this limit the linearity of the $\mathrm{P} x \mathrm{~V}$ relationship tends to be reduced due to the dispersion or instability of the data. Pressure data in this study was within this limit. The equation found for the data in this study was: $\mathrm{V}(\mathrm{mL})=0.747$ (s.e. 0.0733$)+7.23 \mathrm{P}$ (s.e. 0.1165$)+0.101 \mathrm{P}^{2}$ (s.e. 0.0372), $\left(\mathrm{R}^{2}=\right.$ 0.99). This equation differed from the previous one obtained by Mauricio et al. (2003), which used filter crucibles; [V $(\mathrm{mL})=-0.004$ (s. e. $0.06)+4.43 \mathrm{P}$ (s.e. 0.043$)+0.051 \mathrm{P}^{2}$ (s.e. 0.007), $\left.\left(\mathrm{R}^{2}=0.99\right)\right]$. These differences occurred due to changes in the volumes of culture medium $(90 \mathrm{~mL}$ versus $45 \mathrm{~mL})$ and ruminal liquid $(10 \mathrm{~mL}$ versus $5 \mathrm{~mL}$ ), the amount of fermented substrate (1g versus $0.5 \mathrm{~g}$ ), the apparatus used for residue collection (filter crucible versus F57 bag) and, consequently, the volume $(60 \mathrm{~mL}$ versus $110 \mathrm{~mL})$ to be occupied by the gases in each flask (head space) that were used according to the technique described by Mauricio et al. (2003) as opposed to the ones proposed in this study, respectively. In the equation originated in this study, the linear (7.23 versus 4.43$)$ and angular (0.202 versus
0.102) coefficients linked to the variation of the volume of gases in relation to the pressure generated using F57 bags, were superior to the values of the equation proposed by Mauricio et al. (2003), respectively.

Note that in the equation described by Maurício et al. (2003), for each 1.0 psi of pressure registered by the transducer, estimate a production of $4.38 \mathrm{~mL}$ of gases. Using the equation obtained in this study, each 1.0 psi of pressure corresponded to a volume of $8.11 \mathrm{~mL}$ of gases. Although the values are different, results calculated from the volume of gases obtained employing both equations is coherent. Much more so, since the strategy used in the present study for segregation of the incubation residues required the use of only $50 \%$ of the amounts of sample, culture medium and inoculum compared to the original protocol described by Maurício et al. (1999). Therefore, there was approximately double the volume available (head space) for accumulation of gases in the incubation flask.

Thus, the experimental planning using substrate including different parts of the sorghum plant fermented in F57 (Ankom ${ }^{\circledR}$ ) bags, generated a high variability in the data and, therefore, the development of an equation that allowed the estimate of volume by means of the pressure in agreement with the incubation methodology proposed for application in the Laboratory of Gas Production owned by the College of Veterinary Medicine at the Universidade Federal de Minas Gerais (UFMG). 


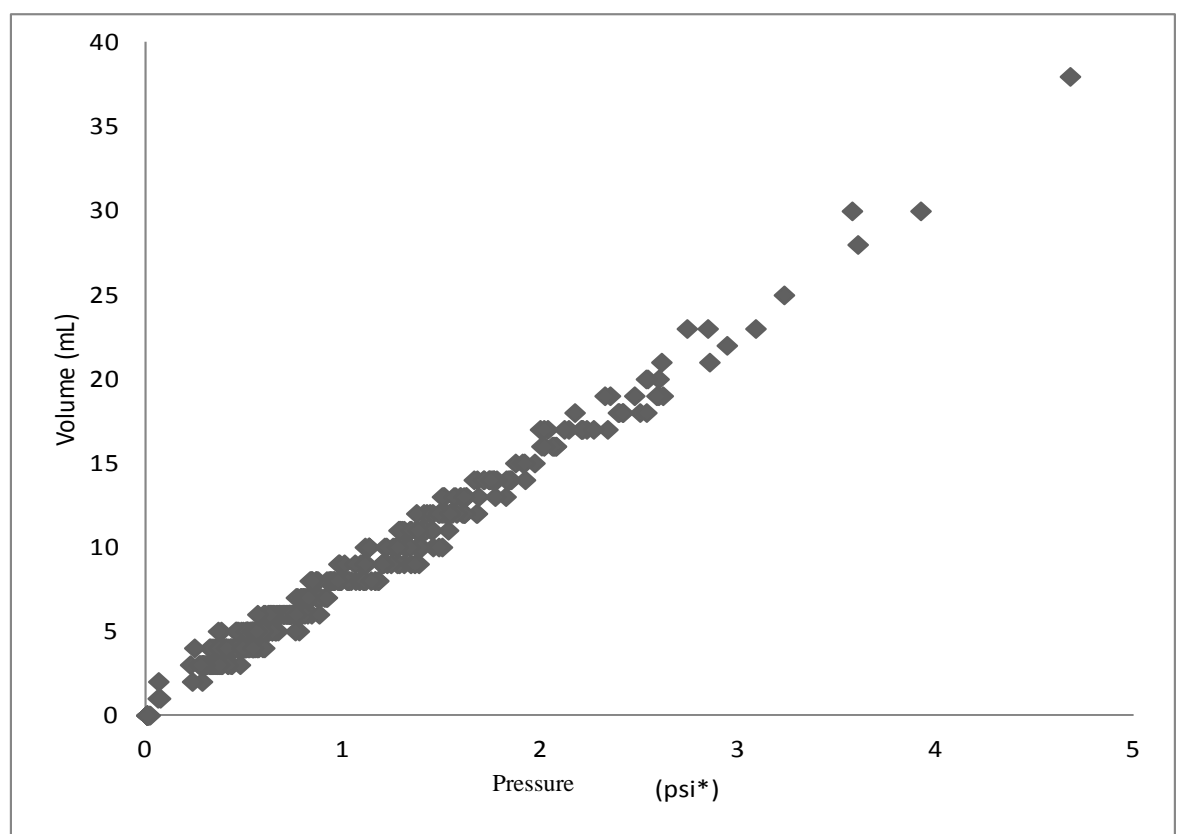

Figure 2. Pressure and volume data obtained through the semi-automatic in vitro technique of gas production, gases which were obtained through the fermentation of parts of the plant (stalk, leaf and panicle) and of the entire sorghum plant BRS506 (*pressure by square inch)

The development of the mathematical equation estimating the volume of gases by means of the pressure using F57 (Ankom ${ }^{\circledR}$ ) bags as a vehicle for substrate fermentation increased the accuracy of the volume determinations and residue deriving from the fermentations using the in vitro semi-automatic technique of gas production installed in the Laboratory of Gas Production of Veterinary School at the Universidade Federal de Minas Gerais.

Keywords: in vitro, forage evaluation, F57 bags, gas production

\section{RESUMO}

Os cadinhos filtrantes (porosidade 1) originalmente usados na técnica in vitro semi-automática de produção de gases estabelecida no Laboratório de Produção de Gases da Escola de Veterinária da UFMG podem ocasionar interferências nos estudos de quantificação da degradação de alimentos, principalmente os ricos em amido, devido à obstrução dos poros da placa filtrante pelo material residual após fermentação. Este estudo objetivou avaliar a substituição dos cadinhos filtrantes por sacos F57 $\left(\right.$ Ankom $\left.{ }^{\circledR}\right)$ visando a realização de experimentos in vitro para descrição da cinética de fermentação $e$ degradação ruminal. Esta substituição causou a redução do peso/volume da amostra incubada e desta forma, interferiu na relação pressão $(P)$ / volume $(V)$ e consequentemente inviabilizou a utilização de equação previamente estabelecida por Mauricio et al. (2003). Desta forma, objetivou-se neste estudo estabelecer equação para estimar o volume de gases produzidos a partir de dados de $P$ e V obtidos pela fermentação de sorgo forrageiro, incluindo partes da planta e planta inteira, incubados em sacos F57 $\left(\right.$ Ankom $\left.{ }^{\circledR}\right)$. Foram quantificados 474 dados simultâneos de pressão e volume os quais variaram de 0 a 4.670 psi e os de volume entre 0 e 38mL. A equação relacionando $P$ e V obtida foi: $V(m L)=0.747$ (s.e. $0.0733)+7.23 P$ (s.e. 0.1165$)+0.101 P^{2}$ (s.e. 0.0372), $\left(R^{2}=0.99\right)$. O desenvolvimento desta equação viabilizou a utilização dos sacos $F 57$ (Ankom $\left.{ }^{\circledR}\right)$ pela na técnica in vitro semi-automática de produção de gases e, portanto permitindo a quantificação dos resíduos da fermentação favorecendo a acurácia dos resultados.

Palavras chaves: in vitro, avaliação de forrageiras, sacos F57, produção de gases 


\section{REFERENCES}

ASSOCIATION OF OFFICIAL ANALYTICAL CHEMISTS - AOAC. Official Methods of Analysis. [15th ed.] Arlington, VA, USA. 1990.

BLÜMMEL, M.; ØRSKOV, E.R. Comparison of "in vitro" gas production and naylon degradability of roughage in predicting feed intake in cattle. Anim. Feed Sci. Technol., v.40, p.109-119, 1993.

GETACHEW, G.; BLÜMMEL, M.; MAKKAR, H.P.S. et al. In vitro gas measuring techniques for assessment of nutritional quality of feeds: a review. Anim. Feed Sci. Technol., v.72, p.261281, 1998.

GUIMARÃES JÚNIOR, R.; FILHO, S.L.S.C.; FERNANDES, F.D.; VILELA, L.; MARTHA JÚNIOR, G.B. Relação entre pressão e volume para implantação da técnica in vitro semiautomática de produção de gases na Embrapa Cerrados. Planaltina: EMBRAPA/CPAC, 2008. 8p. (EMBRAPA/CPAC. Comunicado Técnico, 144).
MAURICIO, R.M.; MOULD, F.L.; DHANOA, M.S. et al. A semi-automated in vitro gas production technique for ruminant feedstuff evaluation. Anim. Feed Sci. Technol., v.79, p.321-330, 1999.

MAURÍCIO, R.M.; PEREIRA, L.G.R.; GONÇALVES, L.C.; RODRIGUES, N.M. Relação entre pressão e volume para implantação da técnica in vitro semi-automática de produção de gases na avaliação de forrageiras tropicais. Arq. Bras. Med. Vet. Zootec., v.55, p.216-219, 2003.

RIBEIRO JÚNIOR, J.I. SAEG - Sistema para análises estatísticas e genética, versão 8.0. Viçosa, MG: Fundação Arthur Bernardes, 2001. 301p.

THEODOROU, M.K.; WILLIAMS, B.A.; DHANOA, M.S. A simple gas production using a pressure transducer to determine the fermentation kinetics of ruminant feeds. Anim. Feed Sci. Technol., v.48, p.185-197, 1994. 